\title{
HUBUNGAN PERSEPSI HARAPAN ORANG TUA TERHADAP PENGAMBILAN JURUSAN SMA/SMK SISWA KELAS VIII SMPN 1 BALONGBENDO
}

\author{
Pief Gustida Aji Rajasa \\ Bimbingan dan Konseling, Fakultas Ilmu Pendidikan, Universitas Negeri Surabaya \\ pief.18071@mhs.unesa.ac.id \\ Ana Tasrijah Jannah \\ Bimbingan dan Konseling, Fakultas Ilmu Pendidikan, Universitas Negeri Surabaya \\ ana.18057@mhs.unesa.ac.id
}

\begin{abstract}
Abstrak
Penelitian ini merupakan hasil observasi yang kami lakukan di lapangan tentang pandangan bagaimana pemilihan jurusan di SMA/SMK pada siswa SMPdipengaruhi oleh harapan orang tua. Tujuan penelitian ini adalah untuk menggambarkan pengaruh harapan orang tua pada siswa kelas VIII SMP Negeri 1 Balongbendo dalam memilih jurusan di SMA/SMK. Penelitian ini merupakan penelitian kuantitatif dengan menggunakan metodedeskriptif korelasional yaitu untuk mengumpulkan informasi mengenai status yang berhubungan mengenai suatu gejala yang ada menurut adanya oada saat penelitian. dengan menggunakan teknik pengumpulan data berupa angket kuisioner dengan jumlah 22 item pertanyaan dan menggunakan skala pengukuran skala likert. Populasi penelitian ini adalah siswa SMP Negeri 1 Balongbendo kelas VIII yang di gunakan sebagai sampel penelitian dengan jumlah sampel adalah 35 orang siswa. Hasil yang ditunjukkan adalah persepsi anak mengenai harapan orangtua sudah mampu menyesuaikan dengan pemilihan jurusan SMA/SMK pada siswa SMP.
\end{abstract}

Kata Kunci:Harapan orang tua, karir, pandangan, pengambilan keputusan

\begin{abstract}
This research is the result of observations we made in the field about the perspective of elections in high school / vocational high school students held by parents' expectations. The purpose of this study was to examine the expectations of parents of eighth grade students of SMP Negeri 1 Balongbendo in choosing majors in high school / vocational school. This research is a quantitative study using a correlational descriptive method using data collection techniques in the form of a questionnaire with a total of 22 question items and using a Likert scale rating scale. The population of this research is students of class VIII of SMP Negeri 1 Balongbendo taken as a sample with a total sample of 35 students. An interesting result is the child's perception of expectations that have been adjusted to the selection of high school / vocational school majors in junior high school students.
\end{abstract}

Keywords: Parental expectations, career, outlook, decision making.

\section{PENDAHULUAN}

Papalia dan Olds memberikan pengertian masa remaja secara implisit. Menurutnya masa remaja adalah masa transisi perkembangan antara masa kanak-kanak dan dewasa yang pada umumnya dimulai pada usia 12 atau 13 tahun dan berakhir pada usia akhir belasan tahun atau awal dua puluh tahun. Sedangkan Anna Freud berpendapat bahwa pada masa remaja terjadi proses perkembangan meliputi perubahan-perubahan yang berhubungan dengan perkembangan psikoseksual, dan juga terjadi perubahan dalam hubungan dengan orangtua dan cita-cita mereka, di mana pembentukan cita-cita merupakan proses pembentukan orientasi masa depan.[uinsuka] Menurut Suherman (2007: 103), remaja (adolescense) diartikan sebagai sesuatu yang "tumbuh" atau "tumbuh menjadi dewasa", secara luas mencakup proses kematangan mental, emosional, social, dan fisik.

Dari berbagai pendapat beberapa tokoh diatas, dapat disimpulkan remaja merupakan fase penting dalam kehidupan dan siklus perkembangan individu. Untuk melewati fase ini tentu individu tersebut harus menjalani tugas tugas perkembangan. Menurut Yusuf (2009:10) fase remaja dibagi menjadi tiga klasifikasi yatitu remaja awal (usia 2-15 tahun), remaja madya (usia 15-18 tahun), dan remaja akhir (19-22 tahun). Sekolah Menengah Pertama (SMP) merupakan jenjang pendidikan yang di tempuh oleh remaja awal dengan usia rata rata 12-15 tahun.

Seperti halnya pengertian remaja menurut anna freud yang mengungkapkan dimana pada masa remaja pembentukan cita cita merupakan proses pembetukan orientasi masa depan individu. Hal tersebut selaras dengan salah satu tugas perkembangan remaja di usia SMP yaitu 
memiliki wawasan persiapan karir. Pada masa remaja udia SMP mereka dihadapkan pada pilihan untuk melanjutkan ke SMA atau SMK yang masing masing memiliki proporsi yang berbeda.

Winkel (2004) mengungkapkan bahwa terdapat beberapa faktor yang memengaruhi pemilihan karier individu yaitu pengaruh lingkungan, stimulus budaya, keluarga serta kondisi sosial ekonomi keluarga. Kata keluarga disebut dua kali sebagai faktor yang memengaruhi pemilhan karier individu ini menujukkan bahwa eksistensi dari pengaruh keluarga sangatlah besar dalam memengaruhi individu dalam perencanaan karier.

Sebuah tantangan terbesar bila harus mengikuti apa yang telah ditentukan oleh orang tua jika tak sesuai dengan keinginan kita. Santrock ( 2012) berpendapat bahwa ia menemukan harapan orang tua mengenai kemandirian anak berbeda beda bergantung pada budaya orang tua dan masa remaja.(Prabowo, Yusuf, \& Setyowati, 2019) Meskipun tak semua orang tua memengaruhi pemilihan karir anak namun mereka memberikan pertimbangan dan arahan kepada anak dalam memilih jurusan di jenjang SMA/SMK. Ikatan antara anak dan orang tua tak bisa dilepas terutama bagi anak remaja yang masih duduk dibangku SMP. Orang tua harus ikut terlibat dalam setiap pengambilan keputusan yang berpengaruh besar baginya (soesandirejo,2017)

Berdasarkan beberapa perspektif diatas penulis bermaksud untuk melakukan penelitian guna mengetahui pengaruh hubungan persepsi harapan orang tua terhadap pengambilan jurursan SMA/SMK siswa kelas VIII SMP Negeri 1 Balongbendo. Dari penelitian ini diharapkan mampu menjadi bahan bacaan dan penambah wawasan serta pengetahuan tentang pengaruh persepsi harapan orang tua dalam pegambilan jurusan siswa di SMP Negeri 1 Balongbendo dan SMP se-kabupaten Sidoarjo.

\section{METODE PENELITIAN}

Pendekatan dalam penelitian ini adalah menggunakan metode deskriptif jenis korelasional penelitian adalah suatu cara yang dipilih untuk memecahkan masalah yang diajukan dalam sebuah penelitian. Sejalan dengan Menurut Best dalam Kusumawati (2015, hlm. 59) penelitian deskriptif adalah salah satu jenis metode penelitian yang berusaha menggambarkan dan menginterprestasikan objek sesuai apa adanya (Tamura, 2018)Peneliti adalah alat utama dalam mengumpulkan data (Meleong, 1997:4,7). Metode pengumpulan data adalah menggunakan menggunakan teknik pengumpulan data berupa kuisioner atau angket sebanyak 22 item. Skala yang digunakan adalah skala persepsi harapan orang tua dan skala kemampuan mengambil jurusan.(Moleong, 2004)

Peneliti menggunakan tipe penelitian ini agar peneliti dapat memperoleh pemahaman dan dapat mendeskripsikan hubungan persepsi orang tua dengan anaknya mengenai pemilihan jurusan di SMA/SMK. Proses hubungan ini di ambil melalui kuisioner sebagai sumber utama yang digunakan peneliti untuk diinterpretasikan menjadi data penelitian.

Populasi penelitian ini adalah siswa SMPN 1 Balongbendo Sidoarjo yang berjumlah 309 siswa kelas VIII dari 9 kelas. Penentuan besar sampel penelitian menggunakan teknik Cluster Sampling atau sampel gugus, karena populasi yang luasdan masih dalam satu wilayah dengan oengambilan sampel yang tetap secara acak.

Teknik analisis data menggunakan dalam penelitian ini dilaksanakan pada 3maret 2020.

\section{HASIL DAN PEMBAHASAN}

Hasil penelitian ini menunjukan bahwa pemiilihan jurusan yang dilakukan oleh siswa SMP masih dipengaruhi oleh persepsi orang tua mengenai masa depan anak Pemilihan jurusan adalah salah satu cara para siswa untuk mendapatkan pendidikan tingkat lanjut sesuai dengan kemampuan yang dia miliki dan mendapatkan pendidikan yang sesuai oleh undang-undang No. 20 tahun 2003 pasal 5 yang menyebutkan secara jelas bahwa setiap warga negara berhak mendapatkan kesempatan meningkatkan pendidikan sepanjang hayat. Artinya masyarakat berhak mendapatkan dan meningkatkan pendidikan yang berpengaruh pada karir yang akan ia capai melalui pemenuhan kemampuan dalam belajar yang ia lakukan selama berpendidikan, dan menempuh pendidikan yang layak.(Kulsum, 2015)

Hubungan orangtua dan anak dalam keluarga terjadi melalui initeraksi komunikasi yang mereka lakukan seharihari. Setiap interaksi orangtua terhadap masa depan karir anak sangat lah penting, dengan harapan yang tinggi orangtua terhadap anaknya membuat orangtua yang menentukan karir anak dengan keinginan orangtua tanpa mengajak komunikasi sang anak, anak apakah pengambilan jurusan yang ditentukan itu sudah cocok dengan bakat dan minat sang anak.(Linamarliyah \& Dewi, 2004)

Dalam proses pengambilan keputusan jurusan pendidikan, interaksi komunikasi antara orangtua dan anak merupakan bagian yang sangat penting. Anak mengkomunikasikan pilihan jurusan yang menjadi minatnya. Informasi dan saran tentang jurusan pendidikan diberikan oleh orangtua kepada anak sebagai bahan pertimbangan untuk memilih jurusan yang tepat. Persepsi orangtua yang tinggi terhadap keinginannya akan anak yang dapat membanggakan tanpa melihat kemampuan anak juga dapat membuat sang anak tertekan dan tidak dapat mengembangkan kemampuan yang ada pada dirinya. Oleh karena itu orangtua dan anak terlibat langsung dalam proses pengambilan keputusan tersebut. Orangtua memberikan kesempatan dan kebebasan kepada anak untuk berpendapat dan juga membimbing anak untuk mampu mengambil keputusan tersebut dengan tepat. Dengan 
begitu persepsi yang negatif dan tidak mendukung akan berkurang dari orangtua terhadap anaknya. (Rini, 2014)

Informan sekolah terhadap kebutuhan siswa Sekolah Menengah Pertama menentukan pilihan siswa untuk melanjutkan di SMA/SMK sesuai dengan kemampuan dan bakat yang mereka miliki masing-masing. Dengan banyaknya pilihan di SMA/SMK ditentukan dengan minat anak terhadap pilihan mata pelajaran yang ada di dalam masing-masing jurusan dan disesuaikan dengan kebutuhan untuk melanjutkan pendidikan ke jenjang perguruan tinggi nantinya. Orangtua dengan mencoba mendengarkan dan memahami alasan-alasan yang disampaikan anak tentang pilihan jurusan yang akan dipilihnya.(Zulaikhah, 2014)

Anak bebas menyampaikan keinginan dan harpaan dalam memutuskan jurusan pendidikan di SMA/SMK, walaupun ada perbedaan pendapat pilihan jurusan pada salah satu pasangan informan orangtua-anak. Perbedaan pendapat dan persepsi timbul karena keinginan dan harapan yang berbeda diantara anak dan orangtua yang menciptakan konflik sehingga mengalami hambatan dalam proses pengambilan keputusan.

Faktor lain yang menentukan proses pengambilan keputusan pemilihan jurusan di SMA/SMK pada siswa, yaitu anak melibatkan teman sebaya untuk mendapatkan saran atau sudut pandang alternatif terkait pilihan jurusan. Di sisi lain, teman sebaya merupakan tempat sharing bagi para siswa untuk bertukan pikiran mengenai jurusan dan sekolah yang akan dia ambil setelah lulus nantinya. Dan pengalaman serta pengetahuan yang sama pada usia remaja juga dapat mempermudah anak dalam berbagi informasi mengenai sekolah dan jurusan yang ada pada setiap sekolah yang ingin ia tuju.(YULYA SARI, 2017)

Orang tua dan anak yang memiliki hubungan persepsi berbeda akan jenjang yang akan dituju anak setelah bersekolah Menengah Pertama merupakan sebuah pemahaman yang harus di selesaikan secara baik agar anak tidak merasa bahwa bakat dan minatnya tidak sesuai dengan jurusan yang ia ambil saat itu. Dengan kebebasan pendapat yang diberikan oleh orang tua kepada anak sangatlah berpengaruh untuk mengembangkan bakat dan minatnya supaya karir yang ia capai nanti tidak keluar dari zona bakat dan minat yang ia asah sejak dulu. Sehingga orangtua dapat bekerja sama dengan anak untuk menentukan karir anak di masa depan.

Tabel 1. Tabel persentase Pengambilan Keputusan karir Siswa terhadap persepsi orang tua

\begin{tabular}{|l|l|l|l|}
\hline \multirow{2}{*}{ Point } & \multicolumn{3}{|c|}{ Jumlah presentase dalam satu poin tertentu } \\
\cline { 2 - 4 } & Poin 14 & Poin 17 & Poin 21 \\
\hline $\begin{array}{l}\text { Hasil dari } \\
\text { setiap } \\
\text { perseentase } \\
\text { pada poin di } \\
\text { bidang karir } \\
\text { yang sudah di } \\
\text { akumulasikan }\end{array}$ & $0.054 \%$ & $0.033 \%$ & \\
\hline
\end{tabular}

\section{PENUTUP}

\section{Simpulan}

Berdasarkan hasil dan pembahasan dalam artikel, kesimpulan penulisan dalam artikel ini adalah pendidikan berkelanjutan merupakan kewajiban karena dapat menentukan karir yang akan ia jalani dikemudian hari, oleh sebab itu peran orang tua dalam memilihkan jurusan yang sesuai dengan anak sangat berpengaruh pada perkembangan anak di jenjang yang lebih tinggi, karena kesempatan belajar yang lebih baik pasti ditentukan dengan jurusan yang sesuai akan kemampuan yang anak miliki. Dengan berinteraksi dan selalu mendekatkan diri kepada anak merupakan kunci untuk orang tua agar memahami kemampuan anaknya secara tidak langsung, selain itu saat di sekolah guru pembimbing juga harus memahami setiap kemampuan peserta didiknya agar dalam pemberian bimbingan kepada mereka tepat sasaran dan tidak membuat peserta didik merasa bahwa dirinya terbebani akan pilihan jurusan yang akan ia ambil di kemudian hari.

Layanan bimbingan dan konseling yang diberikan merupakan bagian dari rangka menguatkan kesadaran peserta didik bahwa peran orang tua juga berpengaruh pada karir mereka, bukan hanya sekedar dari teman dekat saja. Fokus pada pengembangan ini adalah dimana peserta didik mampu bekerja sama dengan orang tua dan guru pembimbing dalam mengembangkan bakat dan minatnya untuk bekal berkarir dikemudian hari dengan bantuan Layanan Dasar yang bertujuan agar peserta duduk mampu membangun karirnya dengan mengembangkan bakatnya secara benar, melalui media yang dikembangkan oleh guru pembimbing.

\section{DAFTAR PUSTAKA}

Arikunto, S. (2006). MetodePenelitian. BinaAksara, Jakarta.

Irianto, A., Aimon, H., Nirwana, H., \& Prasetya, A. T. (n.d.). Komunikasi Interpersonal antara Orang Tua dan Anak Remaja serta Identitas Diri Remaja: Studi 
di Bina Keluarga Remaja Parupuk Tabing, Koto Tangah, Padang, Sumatera Barat. Populasi, 26(1), $16-25$.

Kulsum, K. U. (2015). Hubungan Antara Persepsi Terhadap Harapan Orang Tua Dengan Pemilihan Karir. UNIVERSITAS NEGERI SEMARANG.

Linamarliyah, F., \& Dewi, R. (2004). Persepsi terhadap dukungan orangtua dan pembuatan keputusan karir remaja. Jounal Provitae, 200459.

Moleong, L. J. (2004). Metodologi Penelitian Kualitatif. Bandung: PT Remaja Rosdakarya..(2009). Metodologi Penelitian Kualitatif (Edisi Revisi).

Prabowo, W., Yusuf, M., \& Setyowati, R. (2019). Pengambilan keputusan menentukan jurusan kuliah ditinjau dari student self efficacy dan persepsi terhadap harapan orang tua. Jurnal Psikologi Pendidikan Dan Konseling: Jurnal Kajian Psikologi Pendidikan Dan Bimbingan Konseling, 5(1), 42-48.

Rini, Y. S. (2014). Komunikasi Orangtua-Anak dalam Pengambilan Keputusan Pendidikan. Interaksi: Jurnal Ilmu Komunikasi, 3(2), 112-122.

Saputro, K. Z. (2018). Memahami ciri dan tugas perkembangan masa remaja. Aplikasia: Jurnal Aplikasi Ilmu-Ilmu Agama, 17(1), 25-32.

Tamura, H. (2018). Bab III Kuantitatif pendekatan Korelasional. Journal of Chemical Information and Modeling, 53(9), 287.

YULYA SARI, N. (2017). Pengembangan Buku Panduan Orang Tua Untuk Mendukung Perencanaan Karir Siswa di Madrasah Aliyah Negeri Sidoarjo. Jurnal BK UNESA, 8(1).

Zulaikhah, N. (2014). Hubungan Antara Dukungan Orang Tua Dan Orientasi Karir Dengan Pengambilan Keputusan Studi Lanjut. Universitas Muhammadiyah Surakarta. 